\title{
The Hormonal Control of Larval Diapause in the Rice Stem Borer, Chilo suppressalis
}

\author{
III. Histological Studies on the Neurosecretory Cells of the \\ Brain and the Secretory Cells of the Corpora Allata \\ during Diapause and Post Diapause ${ }^{1}$ \\ By Jun MrtsuHashi and Masatsugu FuKaya \\ National Institute of Agricultural Sciences, Nishigahara, Kita-ku, Tokyo
}

In the previous papers we showed the evidence that the activity of the corpora allata of the rice stem borer larva is maintained through diapause and it decreases gradually towards the termination of diapause (Fukaya \& Mitsuhashi, 1957, 1958). This fact leads us to consider that the endocrine organs which concern metamorphosis or moulting may show some histological changes during diapause and post diapause.

Although there are many literatures of histological works on the neurosecretion, very few of them have been studied with relation to the diapause (FrASER, 1957; Highnam, $1958 \mathrm{a}, \mathrm{b}$ ), and especially as to the larval diapause the research of this kind is lacking at all.

The present paper deals with the results obtained in the experiment in an attempt to ascertain if any histological changes can be seen in such endocrine organ as the brain or the corpus allatum during diapause and post diapause of the rice stem borer larvae.

Thanks are due to Dr. M. Ковау Ashi for his valuable suggestions and to Mrs. E. KuRIHARA for technical assistance.

\section{MATERIALS AND METHODS}

As materials the hibernating larvae belonging to Saigoku ecotype were collected in Tokushima Prefecture in October.
They were kept under natural condition and were fixed at intervals until next June. At the same time, a part of materials was incubated in order to know the degree of diapause intensity.

Since there was a possibility that the larvae collected from fields were already exposed to low temperature which was cold enough to initiate the diapause development, the diapausing larvae reared artificially at $25^{\circ} \mathrm{C}$ from egg stage were also used (Fukaya \& Mitsuhashi, 1958).

The brain and the corpora allata with the surrounding tissues were fixed in Bouin, SusA and SusA-picric for 24 hours respectively. After fixation they were embedded in paraffin wax and sectioned at $5 \mu$. The serial sections were stained with techniques of Gomori's chrome-alumhaematoxylin phloxine, MaLLORY's triple stain and Clark's paraldehyde fuchsin. Clark's paraldehyde fuchsin technique somewhat modified after Susa-picric fixation proved excellent for the purpose of this study.

\section{RESULTS}

General aspect of the neurosecretory cells, the corpora cardiaca and the corpora allata

The neurosecretory cells observed in the brain of the rice stem borer are arranged in six groups, namely, medial, lateral and posterior groups in each half

1 The term " post diapause" is used in the sense that the diapause is followed by a period towards pupation which is characterized by a reduction of corpus allatum activity connecting diapause and lasts about $20 \sim 30$ days at $25^{\circ} \mathrm{C}$ (Fukaya \& Mitsuhashi, 1958).

(Received for publication, April 25, 1960) 


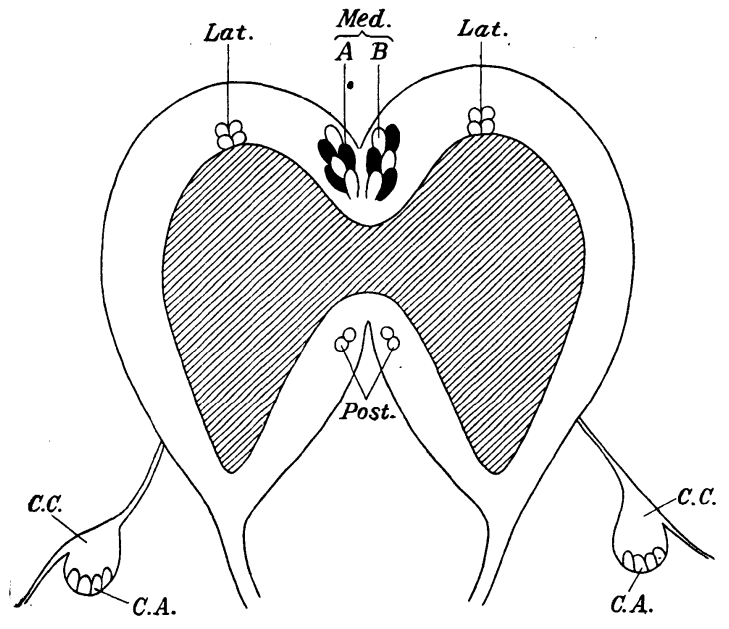

Fig. 1. Neurosecretory cells of the brain and secretory cells of the corpora allata in the rice stem borer larva

A, A-cell of medial group; B, B-cell of medial group; C.A., secretory cells of corpus allatum; C.C., corpus cardiacum; Lat., lateral neurosecretory cell; Med., medial neurosecretory cell; Post., posterior neurosecretory cell. The corpus cardiacum and corpus allatum are somewhat magnified compared with the brain.

of the brain. The medial groups are close together on each side of the midline, on the dorsal and anterior parts of the pars intercerebralis. Each group contains $6 \sim 8$ cells. The lateral groups comprise $2 \sim 4$ cells in each and are situated dorsally about half way along each cerebral lobe. Usually they are found near by the border of medulla. The posterior groups are located on the dorsal and posterior parts of the pars intercerebralis and include $2 \sim 3$ cells in each (Fig. 1). In general, the brains of lepidopterous larvae have two groups of neurosecretory cells in each half of the brain, medial and lateral groups, and no neurosecretory cells have been found on the posterior part of the pars intercerebralis. So the posterior groups observed in the rice stem borer may be of new record ${ }^{1}$.
The medial neurosecretory cells consist of two types of cells which are distinguished each other by their staining reactions. The cytoplasm of the cells belonging to the first type (B-cells) is intensely acidophil. It stains pink, deep red and deep purple with Gomori's, Mallory's and ClaRK's techniques respectively. The second type (A-cells) is not so acidophil as the first type. It stains purple with GOMORI's and MALLORY's and purplish green with Clark's techniques. The first and the second type cells may correspond to the B-cells and the A-cells of the silkworm named by Koвayashi (1957). So we intend to use the same names, A-cells and B-cells also in the rice stem borer.

The lateral and posterior neurosecretory cells stain pale blue with Gomori's and MaLlORY's, and greenish purple with Clark's techniques. In the silkworm the lateral neurosecretory cells show the same staining reactions as B-cells (KoBAYASHI, 1957), whereas in the rice stem borer the lateral neurosecretory cells are different in their staining reactions and behaviors from the B-cells of the medial groups as will be mentioned later. On the other hand, the neurosecretory cells of the posterior groups have almost the same staining properties and behaviors as those of the lateral groups.

The axons from the medial neurosecretory cells cross at the pars intercerebralis and run along the border of the medulla then into the nervi corporis cardiaci. The axons from the lateral and posterior neurosecretory cells could not be traced, so far as this experiment was concerned.

The corpora cardiaca and corpora allata of the rice stem borer are closely attached each other so that no nervi corporis allati are visible. The border between the corpus cardiacum and the corpus allatum is not distinct. The complex of the corpus cardiacum and corpus allatum is covered with a membrane and is connected

1 Recently, also in the silkworm, several neurosecretory cells were found at the same location as in the rice stem borer (KOBAYASHI, personal communication). 
to the brain by the nervus corporis cardiaci. The corpus cardiacum mainly consists of nerve fibers and contains some indistinctly bordered cells. No secretory cells were observed in this organ.

The corpus allatum is made up of two kinds of cells, i. e. the giant secretory cells and the indistinctly bordered small cells. The secretory cells are usually counted by four at the opposite side of the corpus cardiacum.

In general, staining reaction of the complex of the corpus cardiacum and corpus allatum is not so remarkable, but the membrane stains pale blue with Gomori's and Mallory's, and purplish blue with ClaRK's techniques. The cytoplasm of the secretory cells stains pale blue with GoMORI's and MaLlory's, and greenish blue with Clark's techniques. The small cells in the corpus cardiacum as well as the corpus allatum scarcely stain except the chromatin in the nucleus; the cytoplasm stains pale blue and pale greenish blue whereas the chromatin stains purple and orange with MALLORY's and CLARK's techniques respectively.

The acidophil grobules which easily

Table 1. The state of vacuoles in the neurosecretory cells at different stages during diapause and post diapause

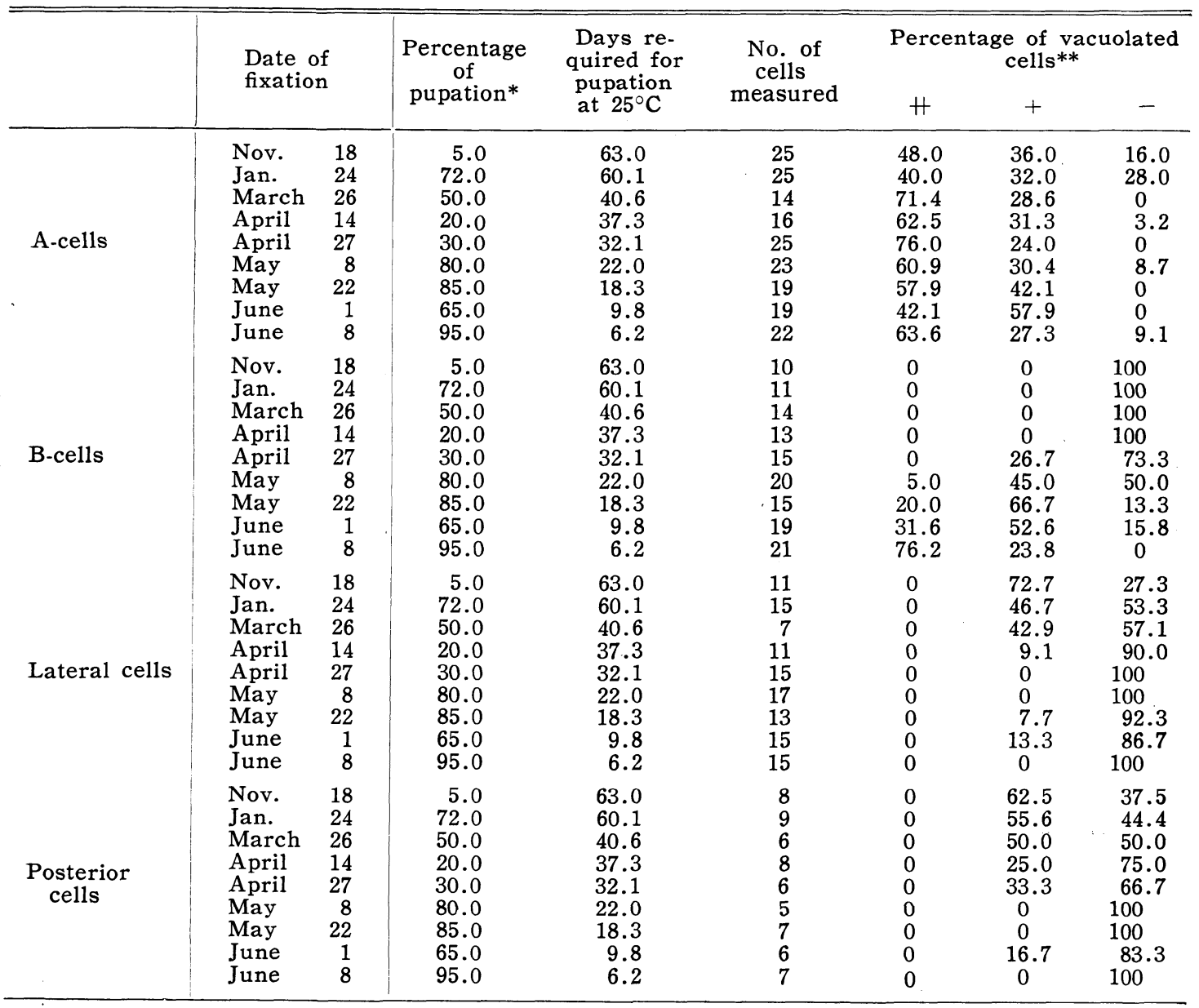

* Twenty larvae were used in each experiment.

** H: Severely vacuolated cells, +: slightly vacuolated cells, - : non-vacuolated cells. 
stain deep red with acid fuchsin of MALLORY's technique were observed in the nervis corporis cardiaci, the corpus cardiacum and also between the cells in the corpus allatum throughout diapause and post diapause periods.

Histology of the neurosecretory cells and the corpora allata during diapause and post diapause

The paraldehyde fuchsin technique was applied here, because it was found to be excellent for this purpose.

Neurosecretory cells.-During diapause the B-cells of the medial groups alone showed a remarkable change. Usually the cytoplasm of the B-cell stains intensely deep purple with paraldehyde fuchsin. In the diapausing period the B-cell stains uniformly and vacuoles are scarcely found in the cytoplasm (Plate 1,I). But with the progress of diapause break small vacuoles appear at first, then gradually become large in size, and unite together following cracks in the cytoplasm. Thus, a few very distinct cracks are found around the nucleus of the B-cell at the time just before pupation (Plate 1, II). The percentage of severely vacuolated cells markedly increases with the advance of diapause break as is clearly shown in Table 1. The vacuolated cells seem to show the active state of the cells liberating their secretory materials. No significant change was observed in the staining reaction of the B-cells at any time during hibernation. They always stain deep purple and even at the vacuolated state remaining part of cytoplasm shows the same staining reaction.

The A-cells of the medial groups, the lateral and the posterior neurosecretory cells did not show any significant histological changes. The A-cell is stained with paraldehyde fuchsin as well as light green, so that the cytoplasm of the A-cell stains purplish green as a whole. At any stages of the diapause and post diapause some of the A-cells are severely vacuolated and the others are not (Plate 1, III, IV). The proportion in numbers of the vacuolated cells and the non-vacuolated cells seems to have no relation to the progress of diapause break (Table 1).

The lateral neurosecretory cells stain purple with paraldehyde fuchsin but not so intensely as the case of the B-cells, and they also stain somewhat green with light green. So the cytoplasm looks greenish purple as a whole. These cells are almost always filled with cytoplasm and are scarcely vacuolated. And even in the rare case where the vacuoles happen to be found in the cytoplasm, the vacuoles are always very small and such large vacuoles or cracks as seen in the medial neurosecretory cells are never observed through diapause and post diapause (Plate $1, \mathrm{~V}, \mathrm{VI}$ ). The morphological state of cytoplasm or the staining property of the lateral neurosecretory cells are considerably stable and

Table 2. The state of secretory cells in the corpora allata at different stages during diapause and post diapause

\begin{tabular}{|c|c|c|c|c|c|c|c|}
\hline \multirow{2}{*}{\multicolumn{2}{|c|}{$\begin{array}{l}\text { Date of } \\
\text { fixation }\end{array}$}} & \multirow{2}{*}{$\begin{array}{c}\begin{array}{c}\text { Percentage } \\
\text { of } \\
\text { pupation* }\end{array} \\
5.0\end{array}$} & \multirow{2}{*}{$\begin{array}{c}\begin{array}{c}\text { Days required } \\
\text { for pupation } \\
\text { at } 25^{\circ} \mathrm{C}\end{array} \\
63.0\end{array}$} & \multirow{2}{*}{$\begin{array}{c}\begin{array}{c}\text { No. of cells } \\
\text { measured }\end{array} \\
30 \\
30\end{array}$} & \multicolumn{3}{|c|}{$\begin{array}{c}\text { Percentage of vacuolated } \\
\text { secretory cells** }\end{array}$} \\
\hline & & & & & H & + & - \\
\hline $\begin{array}{l}\text { Nov. } \\
\text { Jan. } \\
\text { March } \\
\text { April } \\
\text { April } \\
\text { May } \\
\text { May } \\
\text { June } \\
\text { June }\end{array}$ & $\begin{array}{r}18 \\
24 \\
26 \\
14 \\
27 \\
8 \\
22 \\
1 \\
8\end{array}$ & $\begin{array}{r}5.0 \\
72.0 \\
50.0 \\
20.0 \\
30.0 \\
80.0 \\
85.0 \\
65.0 \\
95.0\end{array}$ & $\begin{array}{r}63.0 \\
60.1 \\
40.6 \\
37.3 \\
32.1 \\
22.0 \\
18.3 \\
9.8 \\
6.2\end{array}$ & $\begin{array}{l}30 \\
30 \\
13 \\
17 \\
22 \\
21 \\
24 \\
24 \\
17\end{array}$ & $\begin{array}{l}76.6 \\
73.3 \\
76.9 \\
70.6 \\
81.8 \\
38.1 \\
25.0 \\
4.1 \\
0\end{array}$ & $\begin{array}{l}23.4 \\
26.7 \\
23.1 \\
29.4 \\
18.2 \\
38.1 \\
54.2 \\
29.2 \\
11.8\end{array}$ & $\begin{array}{c}0 \\
0 \\
0 \\
0 \\
0 \\
23.8 \\
20.8 \\
66.7 \\
88.2\end{array}$ \\
\hline
\end{tabular}

*, ** As in Table 1. 
no visible change occurs during diapause and post diapause (Table 1).

The posterior neurosecretory cells stain greenish purple with paraldehyde fuchsin and light green but are more difficult to stain than the lateral neurosecretory cells. They are continuously filled with cytoplasm and are scarcely vacuolated (Table 1). No remarkable change was observed in the posterior neurosecretory cells during diapause and post diapause (Plate 1, VII, VIII).

As to the nucleus little significant differences could be observed in all kinds of the neurosecretory cells of the brain.

Corpora allata.-The secretory cells of the corpora allata markedly change their histological appearance with the progress of the diapause break. During diapause the secretory cells have many large vacuoles and in the most typical cells the vacuoles sometimes unite together and become large apertures in the cytoplasm (Plate 2, IX, XI). These vacuoles exist through diapause period but gradually disappear towards the termination of diapause, and they are completely missing until a few days before pupation (Table 2). At this time the secretory cells are homogeneously filled with cytoplasm (Plate 2, X, XII). The cytoplasm stains greenish blue with paraldehyde fuchsin and mixture of light green, orange $\mathrm{G}$ and chromotorope $2 \mathrm{R}$. This staining property does not change through diapause and post diapause. The small cells of the corpora allata did not show any histological changes during diapause and post diapause.

Measurements of the corpus cardiacum and corpus allatum complex

The short diameter of the corpus cardiacum and corpus allatum complex was measured at its widest part during diapause and post diapause to ascertain if the secretory activity of the corpus allatum is reflected by its volume change. As shown in Fig. 2, the corpus cardiacum and corpus allatum complex maintained its maximum volume during diapause period, then gradually reduced in volume

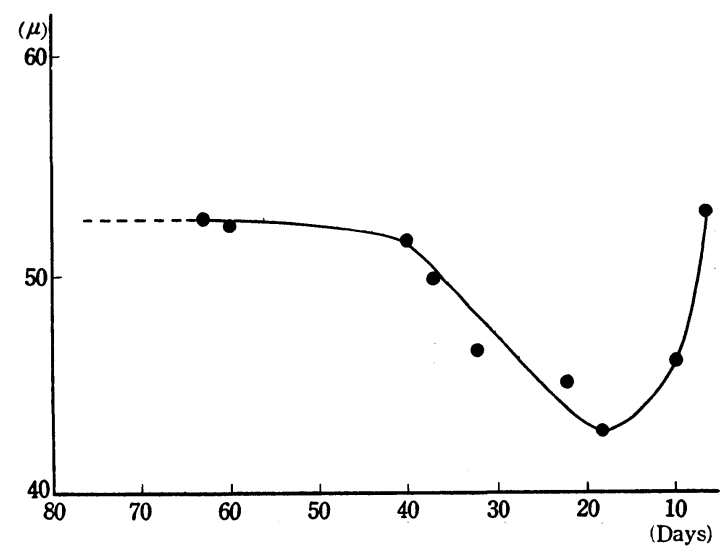

Fig. 2. Change in size of the corpus cardiacum and corpus allatum complex during diapause and post diapause periods Ordinate, short diameter of the corpus cardiacum and corpus allatum complex measured at its widest part. Abscissa, intensity of diapause shown by the days required for pupation at $25^{\circ} \mathrm{C}$.

towards the termination of diapause, and attained its minimum volume about 18 days defore pupation at $25^{\circ} \mathrm{C}$. But it recovered in volume rapidly just before pupation.

Histological observations on the artificially reared larvae

The larvae reared on artificial diet at $25^{\circ} \mathrm{C}$ become full grown about a month after hatching under non-diapause condition, whereas ones kept under diapause condition reach the maximum weight and stop to feed about one and a half months after hatching. The histological appearances of the neurosecretory cells and the corpora allata in the non-diapausing full grown larvae, which pupated within a week at $25^{\circ} \mathrm{C}$ (average is 3.1 days), were quite the same as the case of wild larvae which were awaken from diapause and were just approaching to pupation (Plate 2, XIV, XVI, XVIII). The artificially reared diapausing larvae 50 days after hatching showed about the same histological aspects in the neurosecretory cells and the corpora allata as the wild diapausing larvae which were obtained in 
November and required more than sixty days for pupation at $25^{\circ} \mathrm{C}$ (Plate 2, XIII, XV, XVII).

\section{DISCUSSION}

Although the pupal or larval diapause is generally considered to be caused by temporary lack of metamorphosis hormone, i. e., brain hormone or prothoracic gland hormone (LEES, 1955), an important role of the corpora allata in the maintenance of larval diapause in the rice stem borer cannot be denied at present (FUKAYA \& MitsuHAshi, 1957, 1958). In this regard, the present study seems to give a histological evidence that the secretory cells of the corpora allata are liberating the secretory materials during diapause, and that the secretion is gradually decreased with the progress of diapause break until the time of pupation, when the secretion is stopped at all (Fig. 3). This change in the activity of the corpora allata is presented by the change in the percentage of vacuoles appearing in the secretory cells as well as the volume of the corpus cardiacum and corpus allatum complex. It may be added that the decrease in volume of the corpus cardiacum and corpus allatum complex during post diapause seems to synchronize with the reduction of activity in the corpus allatum which was ascertained by the previous experiments (FUKAYA \& Mitsuhashi, 1958). Although the volume of the corpus cardiacum and corpus allatum complex becomes large again after it attains its minimum volume, the histological appearance of the secretory cells in the corpus allatum remains inactive through this period. This increase in volume may be something but it seems not to have direct connection with the diapause.

As regards the neurosecretory cells of the brain, the role of each group is not yet known, but it has become clear that a part of the neurosecretory cells is continuing its secretion even in diapause period (Fig. 3). Fraser (1957) reported that a certain group of the neurosecretory

\begin{tabular}{|c|c|c|c|c|c|}
\hline & \multicolumn{3}{|c|}{ Neurosecretory cells of brain } & $\begin{array}{c}\text { Secretory } \\
\text { cell of corpus } \\
\text { allatum }\end{array}$ \\
\hline Diapause & Medial A-cell & Medial B-cell & Lateral cell & Posterior cell & \\
\hline $\begin{array}{c}\text { Post } \\
\text { diapause } \\
\text { (a few days } \\
\text { before } \\
\text { pupation }\end{array}$ & & & & & \\
\hline
\end{tabular}

Fig. 3. Morphological differences in the neurosecretory cells of the brain and the secretory cell of the corpus allatum between diapause and post diapause periods 
cells in Lucilia showed an active secretion only in diapause period. But such a group of neurosecretory cells was not observed in the brain of the rice stem borer. Among these neurosecretory cells in the brain of the rice stem borer the B-cells of the medial group alone showed a remarkable change in their activities. Since they are completely inactive during diapause and become active before pupation, it may be presumed that these neurosecretory cells liberate some hormone which is related to metamorphosis. And further, these Bcells change their activities contradictorily with the secretory cells of the corpora allata, so that it may be considered that there is a close relation between them.

Although the role of neurosecretory cells of the brain is obscure yet, it has become evident from the results hitherto obtained in our studies, that the larval diapause of the rice stem borer is pursued by the secretory activity of the corpora allata. It may be noted that the similar aspect has been obtained also in the European corn borer (Mitsuhashi \& Fukaya, unpublished).

Recently Highnam (1958) has suggested that even in the pupal diapause the corpora allata may play some part in the maintenance of diapause. Therefore, such a mechanism as shown in the larval diapause of the rice stem borer may occur widely in other insect species.

\section{SUMMARY}

The neurosecretory cells of the brain and the secretory cells of the corpora allata in the rice stem borer have been investigated histologically through diapause and post diapause.

The neurosecretory cells of the brain consist of three groups in each half of the brain, medial, lateral and posterior groups. The posterior groups may be of new record in the brain of lepidopterous larvae. The medial group comprises two types of neurosecretory cells, A-cells and B-cells.

The histological appearance of the B-cell changes remarkably with the progress of diapause break, i. e., the B-cell looks like inactive during diapause period and becomes active towards the termination of diapause. The other neurosecretory cells did not show any significant change during that period.

Judging from the histological appearance as well as the volume changes of the corpus cardiacum and corpus allatum complex the corpus allatum seems to show high activity during diapause and to lose its activity gradually towards the pupation.

It may be noteworthy that there is a close relation between activities of the corpora allata cells and the B-cells of the brain during diapause and post diapause.

\section{LITERATURE CITED}

Fraser, A. (1957) Nature 179: 257 258 .

Fukaya, M. \& J. Mitsuhashi (1957) Japan. J. Appl. Ent. Zool. 1: 145 154.

Fukaya, M. \& J. Mitsuhashi (1958) Japan. J. Appl. Ent. Zool. 2: 223 226.

Highnam, K. C. (1958a) Quart. J. Micr. Sci. 99: $73 \sim 88$.

Highnam, K. C. (1958b) Quart. J. Micr. Sci. 99: $171 \sim 180$.

Kobayashi, M. (1957). Bull. Sericul. Exp. Sta. 15: $181 \sim 273$.

Lees, A. D. (1957) Cambridge Univ. Press. 151 pp.

\section{EXPLANATIONS OF PLATES}

Plate 1. Neurosecretory cells in the brain stained with CLARK's paraldehyde fuchsin technique after SusA-picric fixation.

A, A-cell; B, B-cell; Cr., crack; Lat., lateral neurosecretory cell; Post., posterior neurosecretory cell; V., vacuole.

I: The B-cell of the medial group at diapausing period. The cell is filled with cytoplasm and vacuoles are absent in the cytoplasm. $\times 1300$.

II: The B-cell of the medial group a few days before pupation. Cracks are present in the cytoplasm. $\times 1300$.

III. The A-cell of the medial group at diapausing period. Large vacuoles are present in the cytoplasm. $\times 1300$.

IV: The A-cell of the medial group a few days before pupation. The state of the cell is the same as that shown in III. $\times 1300$. 
V: The lateral neurosecretory cell at diapausing period. The cell has no large vacuoles in the cytoplasm. $\times 1300$.

VI: The lateral neurosecretory cell a few days before pupation. The state of the cell is the same as that shown in V. $\times 1300$.

VII: The posterior neurosecretory cell at diapausing period. The cell has no large vacuoles in the cytoplasm. $\times 1300$.

VIII: The posterior neurosecretory cell a few days before pupation. The state of the cell is the same as that shown in VII. $\times 1300$.

Plate 2. Neurosecretory cells in the brain and secretory cells in the corpus allatum stained with CLARK's paraldehyde fuchsin technique after SusA-picric fixation.

B, B-cell; C. A., corpus allatum; C. C., corpus cardiacum; Cr., crack; S. C., secretory cell of corpus allatum; V., vacuole.

IX: The corpus cardiacum and corpus allatum complex at diapausing period. The secretory cells of the corpus allatum are severely vacuolated. $\times 650$.

$\mathrm{X}$ : The corpus cardiacum and corpus allatum complex a few days before pupation. The secretory cells of the corpus allatum have no vacuoles. $\times 650$.
XI: The secretory cell of the corpus allatum at diapausing period. Large vacuoles are present in the cytoplasm. $\times 2000$.

XII: The secretory cell of the corpus allatum a few days before pupation. Vacuoles are absent in the cytoplasm. $\times 2000$.

XIII: The B-cell of the medial group obtained from the artificially reared diapausing larva. The cell has no vacuoles. $\times 1300$.

XIV: The B-cell of the medial group obtained from the artificially reared non-diapausing larva a few days before pupation. Crack is present in the cytoplasm. $\times 1300$.

$\mathrm{XV}$ : The corpus cardiacum and corpus allatum complex obtained from the artificially reared diapausing larva. The secretory cells of the corpus allatum are severely vacuolated. $\times 650$.

XVI: The corpus cardiacum and corpus allatum complex obtained from the artificially reared non-diapausing larva a few days before pupation. The secretory cells of the corpus allatum have no vacuoles. $\times 650$.

XVII: The secretory cell of the corpus allatum. The same as XV. $\times 2000$.

XVIII: The secretory cell of the corpus allatum. The same as XVI. $\times 2000$.

$$
\text { ニカメイチュウの幼虫休眠に扣けるホルモン支配 }
$$

III. 休眠期および後休眠期における脸の神経分泌細胞およびアラタ体の 分泌細胞に関する組織学的研究

$$
\begin{aligned}
& \text { 三 橋 淳 · 深 谷 昌 次 } \\
& \text { 農林省農業技術研究所 }
\end{aligned}
$$

ニカメイチュウ脳の神経分泌細胞は中央, 側方および 後方の 3 群からなり, 中央群は更に染色性の異なる A, B 2 種の細胞からなる。アラタ体は数個の巨大な分泌細胞 と輸郭の不めいりょうな小細胞からなり，いんこう（咽 喉）側神経球と密着して一体をなし，その境界は判然と しない。

休眠の覚せい(醒)に伴い, 脳の神経分泌細胞では B 細 胞だけが顕著な变化を示した。すなわち, 休眠中の B 細 胞では細胞質が一様に充実しているが，休眠覚せいとと もに次第に空胞がみられるようになり，よう(蛹)化ま近 かのものでは医大な空胞がみられるに至った。この空胞 のみられる状態は分泌物を放出している活動的な時期と
考えられる。また，アラタ体の分泌細胞ではB細胞とは 逆に，休眠中に巨大な空胞がみられたが，休眠覚せいと ともに空胞は消滅し，ょう化前には巨大な空胞は全くみ られなくなった。

アラタ体いえこう側神経球の複合体は休眠中は大きい が，休眠の覚せいにつれて小さくなり，よう化前約18日 で最小となり，その後再び大きくなることがわかった。 以上の結果から，アラタ体は休眠期中高い活性を維持 しているが，休眠の覚せいに伴って次第に不活性になる ことが推察される。また, 脳のB細胞の活性がアラタ体 の活性と密接に関係していることは注目すべきことであ る。 


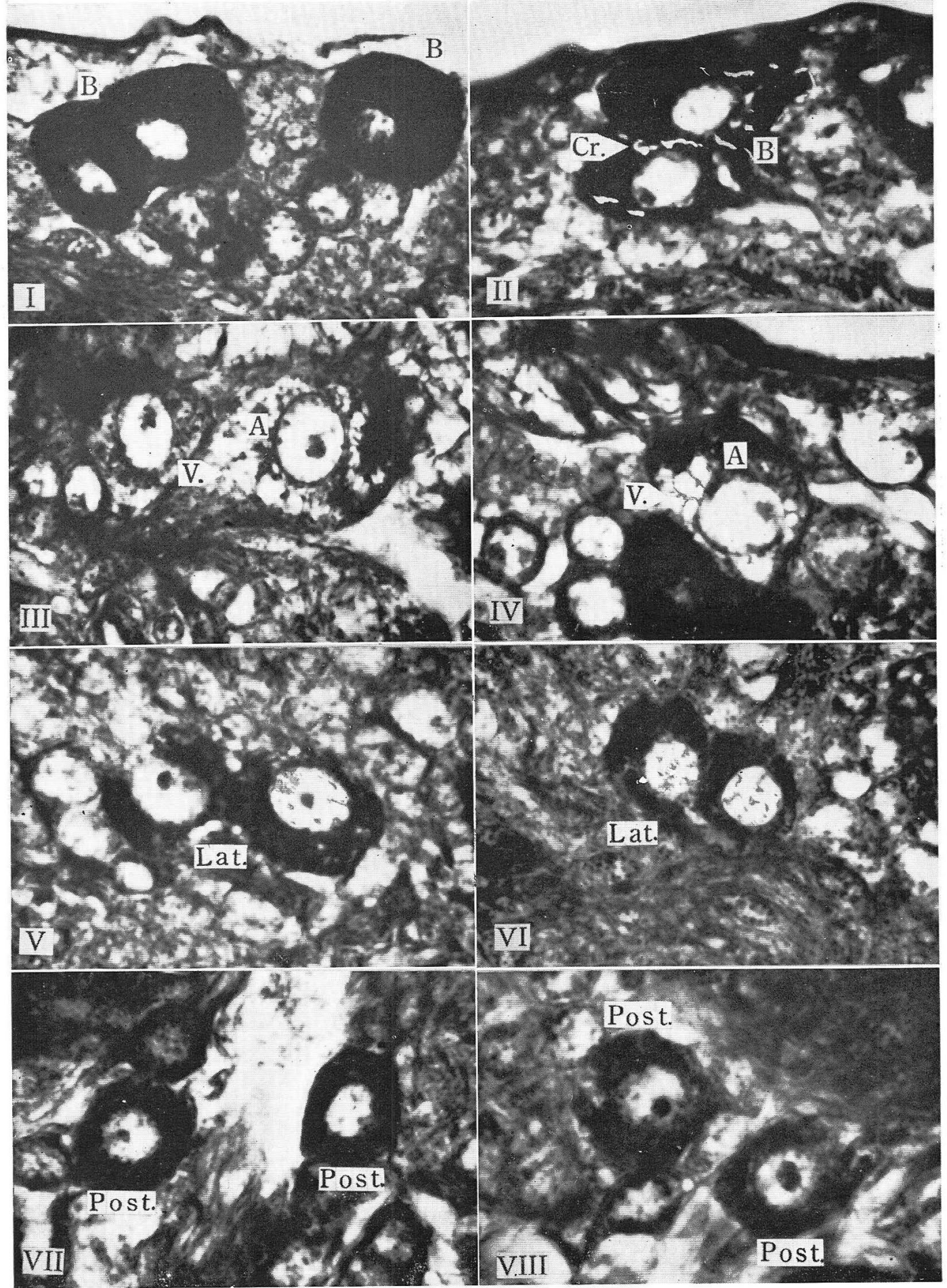


Plate 2
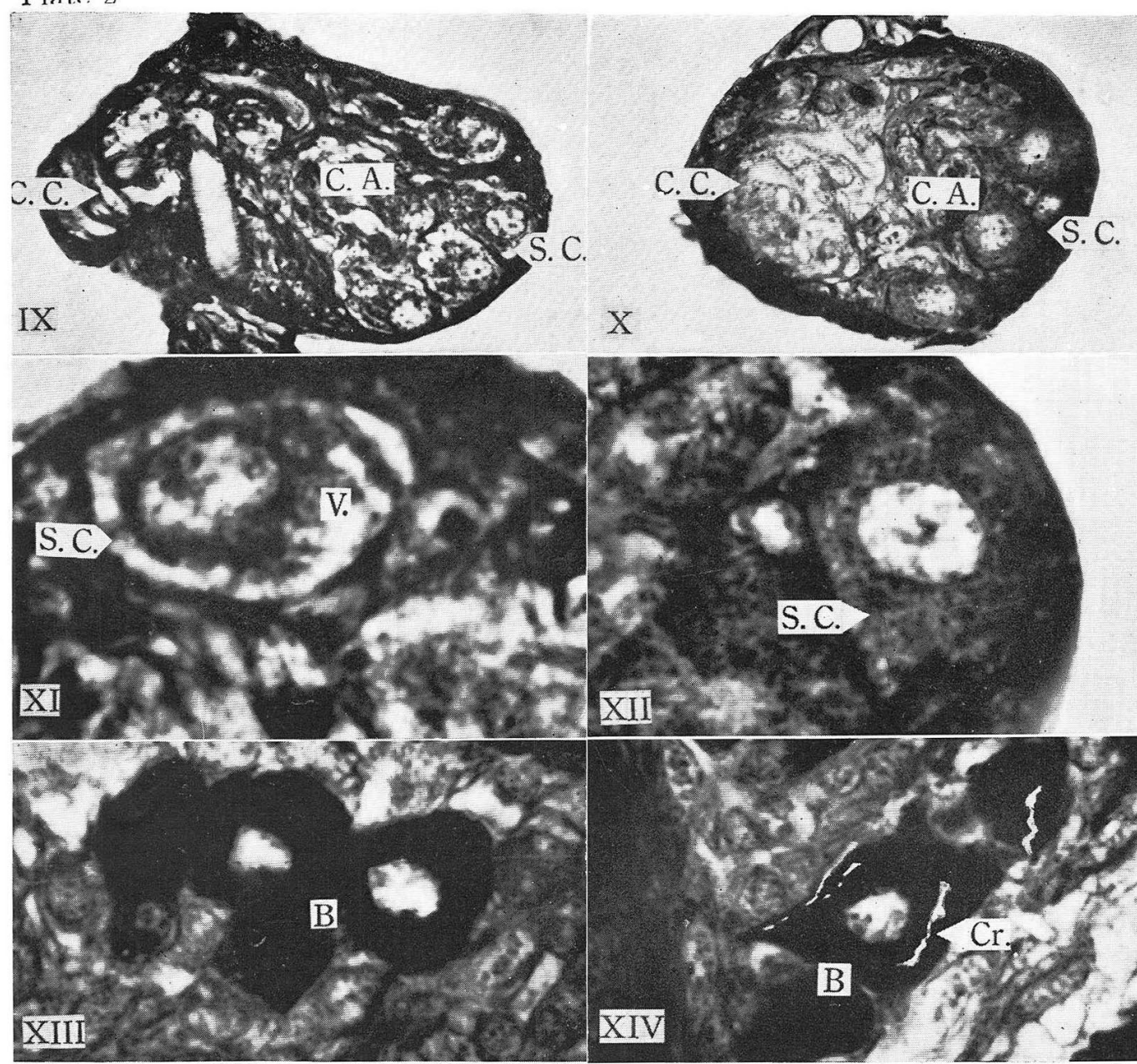

xix

XII

XII -3
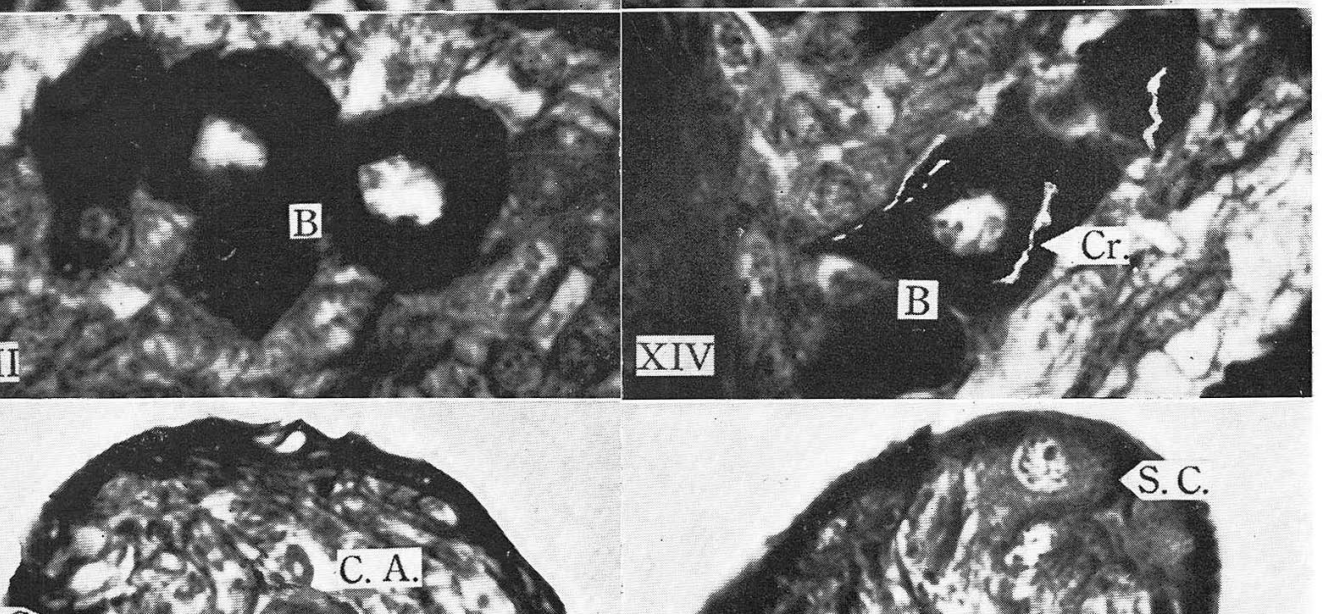

C. C.
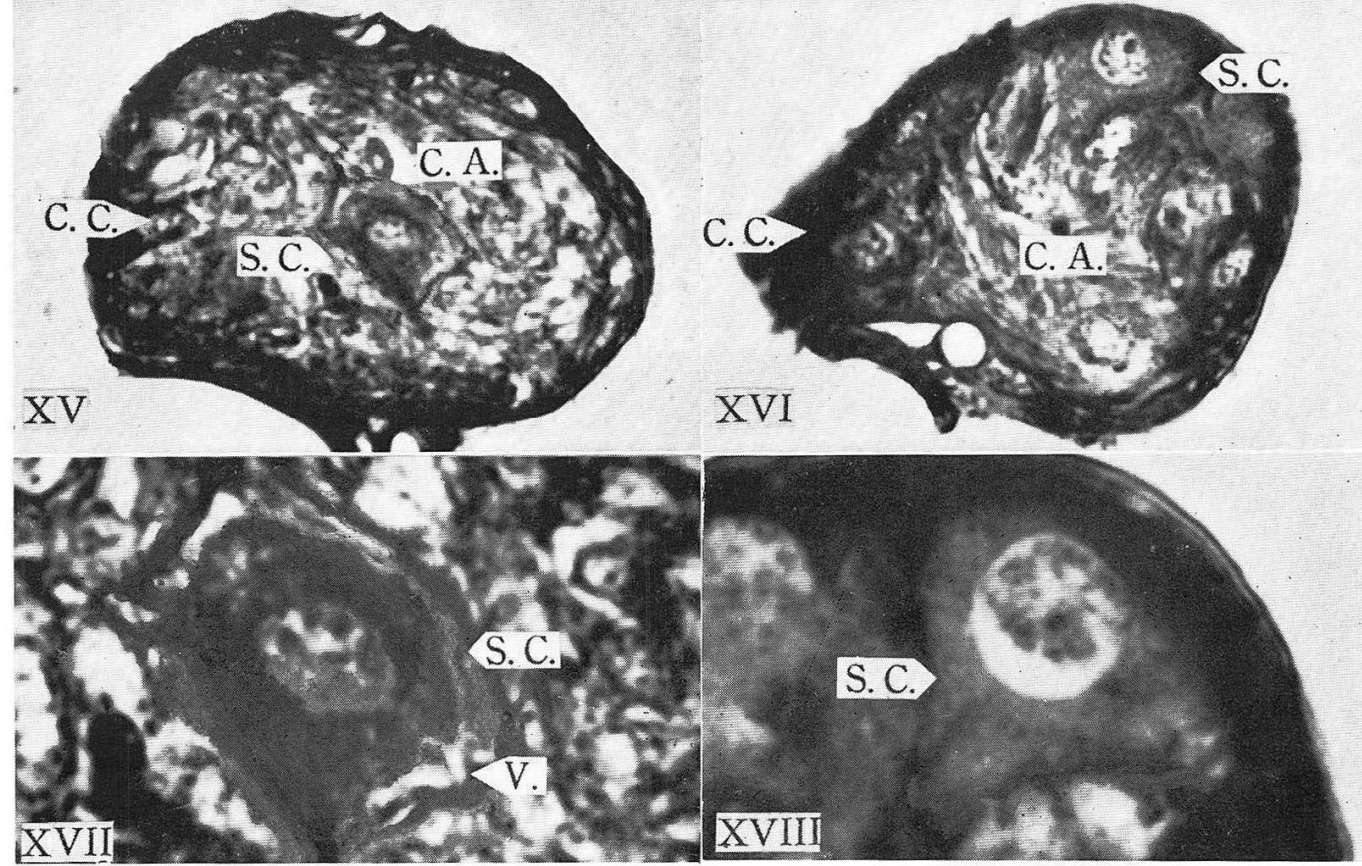